\title{
ANIMAL TUBERCULOSIS AS A POTENTIAL DANGER TO MEN
} \section{GRUŹLICA ZWIERZĄT JAKO POTENCJALNE ZAGROŻENIE DLA CZŁOWIEKA}

\author{
Monika Krajewska $^{1(\mathrm{~A}, \mathrm{~B}, \mathrm{C}, \mathrm{D}, \mathrm{E}, \mathrm{F})}$, Marcin Weiner $^{2(\mathrm{~A}, \mathrm{~B}, \mathrm{C}, \mathrm{D}, \mathrm{E}, \mathrm{F})}$, Ewa Augustynowicz-Kopeć ${ }^{3(\mathrm{~A}, \mathrm{~B}, \mathrm{C}, \mathrm{D}, \mathrm{E}, \mathrm{F})}$
}

${ }^{1}$ National Veterinary Research Institute in Pulawy, Poland

${ }^{2}$ Pope John Paul II State School of Higher Education in Biala Podlaska, Poland

${ }^{3}$ National Tuberculosis and Lung Diseases Research Institute in Warsaw, Poland

Authors' contribution Wkład autorów:

A. Study design/planning zaplanowanie badań B. Data collection/entry zebranie danych

C. Data analysis/statistics dane - analiza i statystyki D. Data interpretation interpretacja danych E. Preparation of manuscript przygotowanie artykułu F. Literature analysis/search wyszukiwanie i analiza literatury G. Funds collection zebranie funduszy
Tables: 0

Figures: 0

References: 23

Submitted: 2016 Jun 23

Accepted: 2016 Aug 01

\section{Summary}

Tuberculosis (latin: tuberculosis) is an infectious disease which affects man and many species of animals. The aetiological factor of tuberculosis are bacillus which belong to the Mycobacterium tuberculosis complex (MTBC) while their host preferences, gene sequence and the level of drug resistance can differ. MTBC constitute a morphologically and biochemically homogeneous group of bacteria which mainly spreads through the aerogenic channel on small, dry particles of phlegm called droplet nuclei which are discharged while infected people or animals cough. Infection occurs after predisposed individual inhales into his or her lungs the bacilli, where they easily multiply in the soft lungs tissue and cause infection. The World Health Organization (WHO) classified bovine tuberculosis (bTB) as direct zoonosis, in which case the transmission of disease is possible without the indirect host's involvement. Moreover, bTB is the best example of anthroponosis, when the disease is transferred from animal to men.

The possibility of dividing the strains of animal bacillus into the two genres: $M$. bovis and $M$. caprae raises some significant legal concerns in Europe since in many of its countries, including among others Poland, caprae is not considered to be an etiological factor of bTB.

Keywords: Mycobacterium tuberculosis complex, bovine tuberculosis, public health, zoonosis, transmission

\section{Streszczenie}

Gruźlica (łac. tuberculosis) jest zakaźną chorobą ludzi i wielu gatunków zwierząt. Czynnikiem etiologicznym gruźlicy są prątki należące do Mycobacterium tuberculosis complex (MTBC), różniące się między sobą różnym powinowactwem do rodzaju gospodarza, sekwencjami $\mathrm{w}$ genach oraz cechami lekooporności. Stanowią niejednorodną grupę pod względem morfologicznym i biochemicznym. Prątki należące do kompleksu tuberculosis przenoszone są głównie drogą aerogenną na małych, wyschniętych cząstkach śluzu zwanych jądrami kropelek (droplet nuclei), które są wydzielane w czasie kaszlu chorych ludzi i zwierząt. Zakażenie następuje, gdy wrażliwy na zakażenie osobnik zaaspiruje prątki do płuc, gdzie w delikatnej tkance mogą się one rozmnażać dając początek infekcji. Zgodnie z klasyfikacją Światowej Organizacji Zdrowia (WHO) gruźlica bydlęca zaliczana jest do zoonoz bezpośrednich, gdzie przeniesienie czynnika infekcyjnego odbywa się bez pomocy żywicieli pośrednich. Ponadto gruźlica zwierząt jest najlepszym przykładem antropozoonozy, gdzie transmisja choroby możliwa jest ze zwierzęcia na człowieka.

Możliwość różnicowania szczepów prątka bydlęcego na gatunki $M$. bovis i $M$. caprae rodzi w Europie istotne wątpliwości prawne, ponieważ $\mathrm{w}$ wielu krajach caprae nie widnieje jako czynnik etiologiczny gruźlicy bydlęcej, w tym $\mathrm{m}$. in. w Polsce.

Słowa kluczowe: Mycobacterium tuberculosis complex, gruźlica bydlęca, zdrowie publiczne, zoonoza, transmisja

\section{Introduction}

Mycobacterium tuberculosis complex (MTBC) are considered as absolute pathogens of men and animals causing tuberculosis. An exception being M. bovis BCG vaccinal - this strain of bovine bacteria underwent the process of attenuation and only in certain circumstances does it trigger symptoms of disease, mainly among people with immunosuppression caused by various reasons or persons with AIDS disease. The etiological factor of bovine tuberculosis (bTB) are bovine bacilli (mycobacteria) - Mycobacterium bovis and Mycobacterium caprae. They are acid-fast, Gram-positive rods which do not show motion or produce aeoras. The time of generation for tubercle 
bacilli in optimum breeding conditions is around 24 hours. Mycobacteria are also rich in lipid content, show acidproof features during staining by Carbol Fuchsin, they are coloured by fluorescent dyes, however, they do not colour during Gram staining. The sizes of these mycobacteria can reach between $1-4 \mu \mathrm{m}$ in length and 0,2 - 0,8 $\mu \mathrm{m}$ in width. Their shape resembles straight or slightly bent rods with rounded ends and rough surface. The latent form of this bacteria can survive for many months and even years inside the human or animal host or in the external environment [1].

Tuberculosis mycobacteria, both human and bovine, are resistant to external environment factors. It tends to react to some chemical or physical agents, such as: high temperature and UV radiation. The bacteria die within 5 seconds at $80^{\circ} \mathrm{C}$, within 10 minutes at $70^{\circ} \mathrm{C}$ and within 20 minutes at $60^{\circ} \mathrm{C}$. On the other hand, it can survive many years in colder or milder temperatures $\left(37^{\circ} \mathrm{C}, 4^{\circ} \mathrm{C},-70^{\circ} \mathrm{C}\right)$. The bacteria are resistant to several factors, which are normally destructive for the cells of living organisms, such as: acids, chemistry bases or detergents. Also, they are resistant to drying and may survive for many years without active metabolism. The high lipid content in cells is responsible for this large resistance being caused by hydrophobic character of their cell wall.

\section{Transmission of tuberculosis between men and animals}

The World Health Organization (WHO) classified bTB as direct zoonosis, where the pathogen is transferred directly from the infected vertebrate to the predisposed one. In terms of bacteria spread direction, the animal tuberculosis can be categorized as any type of zoonosis. The infection is possible to be transferred in two ways, from animal to man (anthropozoonosis) and from man to animal (zoonosis). Infections with human bacteria among domesticated animals occur, above all, in the urban areas where men and animals coexist in a small territory. The problem of the disease caused by $M$. tuberculosis concerns also the wild animals which live in captivity [2,3]. The case of a 30-year-old woman suffering from tuberculosis who transmitted human tuberculosis Mycobacterium tuberculosis to the calf in her farm, was described in 2012 by the group of Polish researchers [4].

\section{Infection transmission between animals}

M. bovis $i$ M. caprae are the main causes of infection among the cattle, carnivorous animals such as dogs and cats and some carnivorous species of birds. They are also the cause of tuberculosis among people and animals belonging to the Primates. The goats, pigs, sheep and cats tend to be more predisposed to infection than dogs and horses [5-7].

In Poland, the biggest natural reservoir of $M$. bovis are infected cattle. The transmission of disease between the herds takes place when the infected animals being asymptomatic carriers are mixed with the healthy ones. Introducing them to the herd free of tuberculosis may cause infection of other animals and growth of the disease. Wild animals which live in the close neighborhood of farms can also be a source of infection [8].

In the United Kingdom, the biggest natural reservoir of M. bovis is the population of the badgers [9], while in Spain of the boars [10]. Transmission of bTB can occur on joint pastures, or rarely, through the bite of a sick animal. In France, the case of women, dog owner, bitten by a badger was described. She contracted tuberculosis caused by M.bovis, four months later her dog started to show the symptoms on the side of the respiratory system and as proved by the washing taken from dog's trachea a strain of bacteria of the same molecular profile which was found in his owner [11].

\section{The pathogenesis of infection among men and animals}

The source of infection with tuberculosis among men is the infected individual who spreads the disease during speaking, breathing and primarily coughing. The bacilli are present in small drops of sputum. After being discharged the droplets of sputum are reduced to small, dry particles called droplet nuclei of 1-5 $\mu$ m diameter. Every droplet contains two to three bacilli which can be inhaled to the alveoli in one's lungs. Transmission can occur during a 15-minute conversation with the infected with tuberculosis individual. One infected, active and infecting individual can transmit tuberculosis to (on average) 10 - 15 persons a year. In the case of animals, the dose nor the time needed for transmission are, so far, unknown. Francis together with his associates, at the end of the 60's of the last century claimed that $50 \mathrm{mg}$ of bovine bacilli injected subcutaneous (s.c.) could kill $94.5 \%$ of Jersey calves in three months. $M$. tuberculosis injected s. c. into cattle inducted infiltration of subcutaneous tissue which underwent caseation, while in about $50 \%$ of infected cattle, nodules in the lung tissue or other organs can be found. Spryszak and Zurawski conducted similar research in the 70's; they injected s.c. into the calves a suspension which contained $5 \mathrm{mg}$ of dried $M$. tuberculosis H37Rv strain. They noticed tubercular lesions in the lungs and other organs, however, the anatomo-pathological findings were similar to those caused by M. bovis AN5 strain. 
The infected cattle, in most of the cases, is the source of infection. The bacilli can be discharged to the environment through all the bodily fluids depending on where the disease process occurs. An intense, mass indoor livestock farming, the way of breeding and the migration among herds facilitate the spread of the disease. Since tuberculosis of animals is located within the area of respiratory system, airborne channel constitutes the most frequent way of infecting cattle by sick animals. The less described channel for infections is through digestive system by consuming contaminated water or fodder. The dairy cattle seem to be more predisposed to infection than the yield cattle. Age and general health state also have a significant impact. The calves may get infected with the disease of their mothers through colostrum, when the udder and the lymph nodes attached to it are infected. Transmission is possible, however rarely, during the pregnancy or labour through umbilical vein of the infected mother. Most often, the disease is transmitted at birth, upon first breaths, so the newly delivered calves should be immediately separated from their infected mother.

Regardless of the way through which the pathogen enters the organism, the inflammation process occurs and the place of primary reaction in tissues is called primary tuberculosis focus (Latin: focus primarius tuberculosus). In most of the cases, the disease is contracted through the droplets, and the lesion is situated in the lungs tissue or chest lymph nodes. When transmission occurs through alimentary canal, the bacteria can pass through the bowel mucous membrane and the primary focus is located in mesenteric lymph nodes which tumefy and form so called bundles. The bacilli can spread to the remaining organs located in abdominal cavity during a long lasting disease process.

The inflammation accompanies the infection of an organism which may be of dual nature: acute -exudative, typical for acute form of a disease and generative. In case of the exudative form of bTB the lymph gathers in alveoli of lungs. This fluid is rich in proteins, leukocytes, lymphocytes, histiocytes and epithelial tissue. In its most frequent progressive phase, tissue can undergo the caseation process in the form of dry, pale yellow lesions. Sometimes, the exudate gets absorbed, or the prolonged inflammation process can cause the formation of granulation tissue. Such case is described as chronic inflammation. The generative form of tuberculosis is characterized by occurrence of typical tubercles or spilt granulation. The tubercle is composed of epithelioid cells arranged concentrically and circumferentially localized lymphoid cells, forming a sort of protective shaft. It is not vascularized, nor does it have elastic fibers. As a result of progressive disease process, tubercle undergoes coagulation necrosis, which resembles dull caseous mate masses. They may become calcified, and in these structures virulent bovine bacilli may survive for years.

\section{Current epidemiological situation of bovine tuberculosis in Poland and Europe}

Over the last five years, 925 heads of cattle were eliminated due to bTB suspicion. In a diagnostic material collected from 435 animals mycobacterium was found, which constituted $47 \%$ of all the cases which were bacteriologically confirmed. Recently, the occurrence of tuberculosis among cattle has increased, for example, in the years $2014-2015$, respectively 196 and 289 heads of cattle were liquidated. The microbiological test in 2014 detected 97 animals infected, whereas in 2015 this number was 183. In 2015, the largest tuberculosis outbreak was recorded in Podlaskie Voivodship where 61 cows were liquidated in the Zambrowki poviat, and 58 in Sokolka poviat. Subsequent largest outbreaks were recorded in West Pomeranian Voivodship (Słowieński poviat) and Greater Poland Voivodship (Pleszewski poviat).

Also, wild animals are often diagnosed with bTB in Poland. By 2015, the disease was discovered in: the zoos, private bison breeding farm in Swiętokrzyskie Voivodship, the Bison Breeding Centre in Smardzewice and Wolisko (Borecka Forest) and in case of some animals living at large in the Bieszczady area [12,13]. At the beginning of 2016 cases of tuberculosis were again recorded in the Borecka Forest, in two bulls examined post mortem. It is sad news for the enthusiasts of these animals, because they came from the unique herd living at large, whose population at the end of 2015 comprised 99 inviduals.

In December 2015, the European Food Safety Authority (EFSA) located in Parma (Italy), together with the European Centre for Disease Prevention and Control (ECDC) located in Stockholm (Sweden) published in an electronic format the annual report on the occurrence in 2014 of zoonotic diseases among people and their etiological factors [14]. In our country, Chief Veterinary Inspectorate is responsible on the technical side of things for the collection and transmission of the relevant data to the EFSA, while information on zoonoses is provided to the ECDC by Chief Sanitary Inspectorate. The outcomes sent by the EU member states and the countries outside of the EU were prepared on the basis of Directive 2003/99 / EC. According to the report, in 2014 Hungary joined the list of countries which were officially free of bTB caused by M. bovis. Among the European countries, which have not yet achieved the status of being free of tuberculosis there are: Bulgaria, Croatia, Cyprus, Greece, Spain, Ireland, Lithuania, Malta, Portugal, Romania, Great Britain and Italy. The United Kingdom is on the first place in Europe, where the reactants rate among cattle is $11.6 \%$; for comparison - in Poland it amounts to less than $0.1 \%$.

The rate of occurrence of bovine tuberculosis among animals in Eastern Europe can be hardly estimated due to lack of available data in this regard. 


\section{Morbidity rate among men caused by bovine bacilli}

Data on tuberculosis among people caused by M. bovis in 2014, presented in Report of EFSA from 2015 came from the $26 \mathrm{EU}$ members (excluding France and Greece), where 145 confirmed cases of the disease were found. Similarly to the previous years, the biggest numbers of infections were registered in Germany - 47 people, in the UK - 39 and in Spain - 34. The other cases were recorded in Austria - 1 person, Belgium - 10, Denmark - 1, Netherlands - 6, Ireland - 3 and Sweden - 4 [14]. According to WHO it is estimated that $1 \%$ of cases of bovine mycobacterium caused disease occurrence among people occur in the countries where the regulations are not supervised well enough. In Poland, so far, two cases caused by M. bovis have been described [15] and one M. caprae case (data not published). All patients came from the southern region of Poland.

\section{Summary}

Despite the fact that Poland, for the last 7 years has been an officially free of bTB, in the last two years, the number of cattle liquidated due to positive tuberculin skin test (TB skin test) has increased, which can be a real danger to human health. The studies showed also that the disease does not concern the individuals only, but the whole herds, and it is probably connected with the new TB skin testing diagram, which covers 1/5 of the cattle population per year. The Zambrowski poviat, where in 2015 the biggest liquidation of cattle took place due to tuberculosis suspicion among cattle, is known for its dairy farming and processing. Despite the fact, that the presently applied milk industry technologies are able to effectively inactivate the bacilli, in light of the public health issue, considering also the survival and easy transmission abilities of this bacteria in the environment, the danger level is high. In 2008, Srivastava and associates described the M. tuberculosis case isolation from cow's milk in India [16]. Moreover, it should be noted that, at many farms unpasteurized, "straight from the caw" milk is consumed, and it is often distributed on the local markets being promoted as organic product.

The new bTB outbreak in Sokólskie poviat is quite alarming. The region borders directly with the Bialystok poviat, where Knyszyn Forest is situated which is home to around 100 bisons living at large. The Bialowieza Forest inhabited by the largest population of free-living European bison (578 individuals) is nearby. The hazard to people getting infected is even greater, as the bison are a huge and an increasing popular tourist attraction and their places of stay have become commonly visited by the organized tours of school youth and even by pre-school children.

The animals in zoo, suffering from tuberculosis can be a real danger to the visitors and to the staff. Over the last 20 years, bovine tuberculosis has been found in the following zoos: Gdansk ZOO, Poznan ZOO, Wroclaw ZOO and Chorzow Z0O [17-19].

The cooperation with Polish zoological gardens showed that often times legal and safety procedures are not being followed. The most common issue is the failure to perform TB skin test before putting the animal in the deposit to another zoo. It is dictated by a strong confidence regarding animal's health in the home zoo and the lack of suspicion related to the particular individual. Besides, difficulties with pharmacological immobilization of a given animal or unforeseen effects while waking up the animal (that may lead to death) often occur. There is no sufficient information on the animals in zoos, their contagious diseases and even such fact being often suppressed, making it even more difficult to conduct epidemiological investigations and find the source of tuberculosis infection.

Implementation of modern molecular biology methods and observation of new bTB outbreaks among cattle are crucial for the elimination strategy [20]. The main task for counteracting tuberculosis is the ability to find the sources of infection (case detection). Standardization of the applied methods allows for comparing different patterns of genetic strains spread around the world and controlling their global spreading. Knowledge provided by the molecular epidemiology of tuberculosis together with profound observation, should allow us to control transmission of tuberculosis in the environment. Identifying the epidemiological chain is very important in terms of wild animals, as there is no tuberculin standardization hence many problems occur, such as immobilization of the animal in order to perform such a test or other by living actions, for example, taking blood test for the Gamma-interference test [21].

District Veterinary Officer and District Sanitary Inspector are obligated to inform each other about tuberculosis infection cases among men who live with animals, and in case of the disease occurrence in cattle. Moreover, in the framework of joint cooperation in fighting against the infections and zoonotic diseases the State Sanitary Inspection and Veterinary Inspection should exchange information on epidemiological situations.

If tuberculosis occurs concerns animals in captivity, both in the zoos or private breeding farms, their cages and enclosures of infected animals should be thoroughly sanitized with anti-bacteria substances. The entire human personnel should be tested as persons of direct contact and they should have TB skin test made, preferably accompanied by interferon T-SPOT.TB test [22], lung X-ray and a thorough testing of the symptoms, such as: fever, cough, sudden weight loss, etc. The literature described the cases, in which the infected human was the source of infection for the animals, as it happened at the elephant farm in Illinois in the USA [23]. 
The civilizational progress which has taken place over the last several dozen years made it possible, thanks to the commitment of the veterinary and sanitary services, to eliminate tuberculosis occurrence in cattle, and by this reduced the risks of its occurrence among people. On the other hand, freedom of movement, international animal origin food trade, increasing number of private zoos and agri-tourism farms the key attraction of which are the animals considered so far as living at large cause that one must bear in mind the new, potential infection sources.

\section{References:}

1. Kozioł-Montewka M, Pańczuk A, Tokarska-Rodak M, Paluch-Oleś J, Gładysz I, Sikora A, et al. Current infectious threats associated with the development of civilization and progress in medicine - methods of prevention and education. Health Problems of Civilization. 2014; 8: 6-14.

2. Montali RJ, Mikota SK, Cheng LI. Mycobacterium tuberculosis in zoo and wildlife species. Rev Sci Tech 2001; 20: 291-303.

3. Pavlik I, Machackova M, Yayo Ayele W, Lamka J, Parmova I, Melicharek I, et al. Incidence of bovine tuberculosis in wild and domestic animals other than cattle in six Central European countries during 1990-1999. Vet Med Czech. 2002; 5: 122-131.

4. Krajewska M, Kozińska M, Zwolska Z, Lipiec M, Augustynowicz-Kopeć E, Szulowski K. Human as a source of tuberculosis for cattle. First evidence of transmission in Poland. Vet Microbiol. 2012; 159: 269-271.

5. Crawshaw T, Daniel R, Clifton-Hadley R, Clark J, Evans H, Rolfe S, et al. TB in goats caused by Mycobacterium bovis. Vet Rec. 2008; 163: 127.

6. Monreal L, Segura D, Segalés J, Garrido JM, Prades M. Diagnosis of Mycobacterium bovis infection in a mare. Vet Rec. 2001; 149: 712-714.

7. van der Burgt GM, Crawshaw T, Foster AP, Denny DJ, Schock A. Mycobacterium bovis infection in dogs. Vet Rec. 2009; 165: 634.

8. Corner LA. The role of wild animal populations in the epidemiology of tuberculosis in domestic animals: how to assess the risk. Vet Microbiol. 2006; 112: 303-312.

9. Gallagher J, Clifton-Hadley RS. Tuberculosis in badgers; a review of the disease and its significance for other animals. Res Vet Sci. 2000; 69: 203-217.

10. Beltrán-Beck B, Ballestros C,Vicente J, de la Fuente J, Gortázar C.Progress in Oral Vaccination againstTuberculosis in Its Main Wildlife Resevoir in Iberia, the Eurasian Wild Boar. Vet Med Int 2012. doi: 10.1155/2012/978501.

11. Shrikrishana D, de la Rua-Domenech R, Smith NH, Colloff A, Coutts I. Human and canine pulmonary Mycobacterium bovis infections in the same household: re-emergence of an old zoonotic threat? Thorax 2009; 64: 89-91.

12. Krajewska M, Lipiec M, Zabost A, Augustynowicz-Kopeć E, Szulowski K. Bovine Tuberculosis in a Wild Boar (Sus scrofa) in Poland. J Wildl Dis. 2014; 50: 1001-1002.

13. Krajewska M, Zabost A, Welz M, Lipiec M, Orłowska B, Anusz K, et al. Transmission of Mycobacterium caprae in a herd of European bison in the Bieszczady Mountains, Southern Poland. Eur J Wildlife Res. 2015; 61: 429-433.

14. Osek J, Wieczorek K. Prevalence of bacterial zoonoses in humans and zoonotic agents in animals and in food in the European Union in 2014. Życie Wet 2016; 91: 193-198.

15. Kozińska M, Zientek J, Augustynowicz-Kopeć E, Zwolska Z, Kozielski J. Transmission of tuberculosis among people living in the border areas of Poland, the Czech Republic, and Slovakia. Pol Arch Med Wewn. 2016; 126(1-2): 32-40.

16. Srivastava K, Chauhan DS, Gupta P, Singh HB, Sharma VD, Yadav VS, et al. Isolation of Mycobacterium bovis \& M. tuberculosis from cattle of same farms in north India-possible relevance in human health. Indian J Med Res. 2008; 128: 26-31.

17. Kalicki M, Krajewska M. Case of tuberculosis in a Deffasa Waterbuck (Kobus ellipsiprymnus deffasa). Med. Weter. 2011; 67(7): 499-500.

18. Augustynowicz-Kopeć E, Krajewska M, ZabostA, Napiórkowska A, Zwolska Z. Characterisation ofMycobacterium bovis strains isolated from farm and wild animals from Poland. Bull Vet Inst Pulawy 2011; 55: 381-383.

19. Krajewska M, Załuski M, Zabost A, Orłowska B, Augustynowicz-Kopeć E, Anusz K, et al. Tuberculosis in Antelopes in a Zoo in Poland - Problem of Public Health. Pol J Microbiol. 2015; 4: 405-407.

20. Hilty M, Diguimbaye C, Schelling E, Baggi F, Tanner M, Zinsstag J. Evaluation of the discriminatory power of variable number tandem repeat (VNTR) typing of Mycobacterium bovis strains. Vet Microbiol. 2005; 109: 217-222.

21. Krzysiak MK, Larska M. Immobilizacja farmakologiczna żubrów. Med Weter 2014; 70: 172-175 (in Polish).

22. Borkowska D, Zwolska Z, Michałowska-Mitczuk D, Korzeniewska-Koseła M, Zabost A, Napiórkowska A, et al. Interferon-gamma assays T-SPOT.tb for the diagnosis of latent tuberculosis infection. Pneumol Alergol Pol. 2011; 79(4): 264-271.

23. Michalak K, Austin C, Diesel S, Bacon MJ, Zimmerman P, Maslow JN. Mycobacterium tuberculosis infection as a zoonotic disease: transmission between humans and elephants. Emerg Infect Dis. 1998; 4(2): 283-287. 